\title{
Synthesis and Evaluation the Activity of 1, 3, 4-Thiadiazole Derivatives as Antibacterial Agent Against Common Pathogenic Bacteria
}

\author{
Evon Akram *1, Shaymaa Naji Daham ${ }^{2}$, Alaa Adnan Rashad ${ }^{1}$ and Asmaa Easa Mahmood ${ }^{3}$ \\ ${ }^{1}$ Department of Chemistry, College of Science, Al-Nahrain University, Baghdad-Iraq. \\ ${ }^{2}$ Department of Biology, College of Education, Samarra University, Samarra-Iraq. \\ ${ }^{3}$ Department of Pathological Analyzes, College of Applied Sciences, Samarra University, \\ Samarra-Iraq. \\ * Corresponding Author: evc.jabar@gmail.com
}

\begin{abstract}
Schiff base compound 5-(benzylideneamino)-1,3,4-thiadiazole-2-thiol was prepared from condensation reaction of 2-amino-5-mercapto-1,3,4-thiadiazole with benzaldehyde. Schiff bases react with Copper(II), Ferric(III), Cobalt(II) and Zinc(II) to form four complexes. The Schiff base complexes were identification by using FTIR and UV-VIS. The antibacterial activity of complexes (Copper(II), Ferric(III), Cobalt(II) and Zinc(II)) were studied against $S$. aureus and $S$. epidermidis as a model of Gram positive, E. coli, P. mirabilis, C. freundii and P. aeruginosa as a Gram negative model to determine activity of synthesized complexes, after subjected them to some tests to confirm the identity of the pathogenic bacteria. Ten antibiotics (Ampicillin and Amoxicillin) have been chosen to investigate the ability of bacterial isolates to resistant the conventional antibiotic. Imipenem have been selected to contrast its efficiency with those of the new compounds because of its high efficiency. The results exhibited higher activity of the new compounds proportional to the chosen antibiotics.

[DOI: 10.22401/ANJS.22.1.04]
\end{abstract}

Keywords: Synthesis, 1, 3, 4-thiadiazole, antibiotic, antibacterial.

\section{Introduction}

Thiadiazoles was five membered aromatic ring compounds with three hetero atoms one sulfur atom and two nitrogen atoms[1].There were four isomeric types of thiadiazoles[2]: (a)1,2,3-thiadiazole; (b)1,3,4-thiadiazole; (c) 1,2,4-thiadiazole; and (d) 1,2,5-thiadiazole. The most thermally stable isomer were $1,3,4$ thiadiazole and its stability were controlled in general by the electron density at the $\mathrm{C}_{2}$ and $\mathrm{C}_{5}$ atoms which was largely dependent on the substituents. The stability of 1, 3, 4-thiadiazole is especially enhanced by alkyl and aryl substituents on positions 2 and 5. Thiadiazoles like all other compounds containing (-NH$\mathrm{CH}=\mathrm{X})$ moiety $(\mathrm{X}=\mathrm{N}, \mathrm{O}$ and $\mathrm{S})$ exist in two tautomeric forms [3]. 1,3,4-thiadiazol ring system shown antifungal, bacteriostatic and containing compounds perform substantial class of heterocyclic nitrogen compounds and their derivatives were recognized with a broad spectrum of biological activity in both agrochemical[4] as well as anthelmintic effects.

The growing numbers of antimicrobialresistant pathogens place a significant burden on healthcare systems and have important global economic costs. Resistance was realized as bacteria that are not inhibited by commonly achievable systemic concentration of an agent with ordinary dosage schedule; multiple drug resistance was acquainted as the resistance to two or more drugs or drug portion [5]. Both Schiff bases and azo compounds were important structures in the medicinal and pharmaceutical fields and it had been proposed that the azomethine linkage might be responsible for biological activities displayed by Schiff bases [6]. Hence the current work was the need for the development of novel antimicrobial agents to combat the bacterial infections [7].

\section{Experimental}

\section{A. Preparation of 2-amino-5-mercapto- 1,3,4-thiadiazole \\ 2-amino-5-mercapto-1,3,4-thiadiazole}

Scheme (1) was synthesized as previously reported[8], yellow needle crystal form, melting point was reported $(180-185)^{\circ} \mathrm{C}$. 


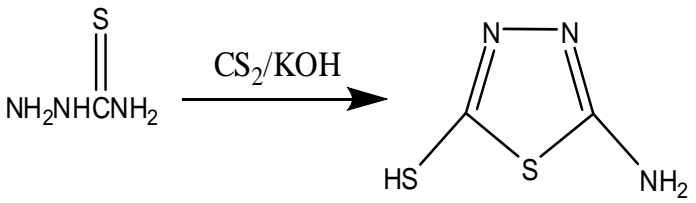

Scheme (1): Preparation of 2-amino-5mercapto-1,3,4-thiadiazole.

Preparation of 5-(benzylideneamino)-1,3,4thiadiazole-2-thiol

\section{B. Preparation of 5-(benzylideneamino)-} 1,3,4-thiadiazole-2-thiol

5-(benzylideneamino)-1,3,4-thiadiazole-2thiol scheme (2) was synthesized as previously reported [9], white crystal precipitate, melting point was reported $(140-145)^{\circ} \mathrm{C}$.

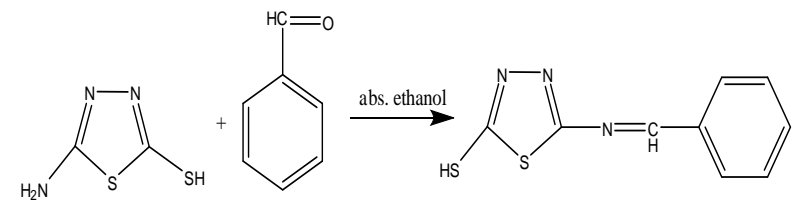

Scheme (2): Preparation of 5 (benzylideneamino)-1,3,4-thiadiazole-2-thiol.

C. Preparation of 5-(benzylideneamino)1,3,4-thiadiazole-2-thiol complexes

All

5-(benzylideneamino)-1,3,4thiadiazole-2-thiol complexes were prepared according to previously papers [10], [11].

\section{Copper (II) complexes ( $\left.\mathbf{A}_{1}\right)$}

Add $(0.219 \mathrm{~g}, \quad 0.002 \mathrm{~mole})$ of 5(benzylideneamino)-1,3,4 thiadiazole-2-thiol to alcoholic solution $\left[\mathrm{CuCl}_{2} \cdot 2 \mathrm{H}_{2} \mathrm{O}(0.341 \mathrm{~g}\right.$, $0.001 \mathrm{~mole}$ ) in $10 \mathrm{ml}$ of abs. ethanol], then the mixture was refluxed for $3 \mathrm{hrs}$. The gray precipitate was product and then filtered and washed with absolute ethanol and dried it in room temperature.

\section{Ferric(III) complexes $\left(\mathbf{A}_{2}\right)$}

Add $(0.219 \mathrm{~g}, \quad 0.002 \mathrm{~mole})$ of 5(benzylideneamino)-1,3,4-thiadiazole-2-thiol to alcoholic solution $\left[\mathrm{FeCl}_{3} \cdot 6 \mathrm{H}_{2} \mathrm{O}(0.273 \mathrm{~g}\right.$, $0.001 \mathrm{~mole}$ ) in $10 \mathrm{ml}$ of abs. ethanol], then the mixture was refluxed for $3 \mathrm{hrs}$. The gelatinous olive precipitate was product and then filtered and washed with absolute ethanol and dried it in vacuum.

\section{Cobalt (II) complexes $\left(\mathbf{A}_{3}\right)$}

Add $(0.219 \mathrm{~g}, \quad 0.002$ mole $)$ of 5(benzylideneamino)-1,3,4-thiadiazole-2-thiol to alcoholic solution $\left[\mathrm{CoCl}_{2} \cdot 6 \mathrm{H}_{2} \mathrm{O} \quad(0.23 \mathrm{~g}\right.$, 0.001 mole) in $10 \mathrm{ml}$ of abs. ethanol], the mixture was refluxed for $3 \mathrm{hrs}$. The brown precipitate was product and then filtered and washed it with abs. ethanol and dried it in room temperature.

\section{Zinc (II) complexes $\left(\mathbf{A}_{4}\right)$}

Add (0.219 g, 0.002 mole) of 5(benzylideneamino)-1,3,4-thiadiazole-2-thiol

to alcoholic solution $\left[\mathrm{ZnCl}_{2} \cdot 2 \mathrm{H}_{2} \mathrm{O}(0.237 \mathrm{~g}\right.$, 0.001 mole) in $10 \mathrm{ml}$ of abs. ethanol], the mixture was refluxed for $3 \mathrm{hrs}$. The yellow gelatinous precipitate was product and then filtered and washed it with abs. ethanol and dried it in room temperature.

\section{Collection of pathogenic bacterial isolates}

All pathogenic bacteria were obtained from the Salah El Din Hospitals. The identification of bacteria was performed using VITEK2 compact system. The pathogenic bacterial isolate were cultivated on selective media in the laboratory and stained by Gram stain and some biochemical tests were done as confirmation diagnostic tests [12]. All the collected isolates were isolated from different site of infection.

\section{Antimicrobial susceptibility patterns}

The disc diffusion method was used to determine antibiotic sensitivity of the isolates [13]. pure colony transferred to clean tube contain $4 \mathrm{ml}$ brain heart infusion broth and incubated at $37^{\circ} \mathrm{C}$ for $4-5$ hours and compared to $0.5 \mathrm{McF}$ arland standards $\left(1.5 \times 10^{8}\right)$. Then spread on Mueller Hinton agar plates (Himedia/ India). The plates were dried at room temperature for $2 \mathrm{~h}$. Antibiotic discs were placed at equi-distances. The plates were incubated for $24 \mathrm{~h}$ at $37^{\circ} \mathrm{C}$ and organisms were categorized as sensitive or resistant, based on the standards [14]. (A total of 10 antibiotics used in this study: Amikacin, Amoxicillin/Clavulanic acid, Azithromycin, Carbencillin, Ceftazidime, Clarithromycin, Imipenem, Levofloxacin, Norfloxacin, Tigecycline/ Bioanalyse/ India).

\section{Antibacterial activity of complexes}

The antibacterial activities of synthesized complexes were evaluated against some pathogenic bacteria (E.coli, P.mirabilis. 
C.freundii, P.aeruginosa, S.aureus and S.epidermidis) using well diffusion method. $0.2 \mathrm{ml}$ of fresh cultures of each organism was inoculated into $5 \mathrm{ml}$ of sterile nutrient broth (Himedia/ India) and incubated for 3-5 h to standardize the culture to McFarland standards $\left(10^{6} \mathrm{CFC} / \mathrm{ml}\right) .0 .1 \mathrm{ml}$ of each culture of microorganism was spreading on Mueller Hinton Agar. Wells were made using gel puncture (6mm) according to [15] with modifications, then $0.1 \mathrm{~mL}$ of different dilutions $(0.1,0.03 .0 .05 \mathrm{M})$ in case of Copper(II) complexes: (Dissolved Copper(II) complexes $(0.1 \mathrm{~g}, 0.2 \mathrm{~g}$ and $0.3 \mathrm{~g})$ in $2 \mathrm{ml}$ DMSO), while the dilutions $(0.1,0.2,0,3 \mathrm{M})$ in case of Ferric(III) complexes: (Dissolved $(0.1 \mathrm{~g}, \quad 0.2 \mathrm{~g}$ and $0.3 \mathrm{~g})$ of Ferric(III) complexes in $2 \mathrm{ml}$ abs. ethanol), Cobalt(II) complexes: $(0.1 \mathrm{~g}, 0.3 \mathrm{~g}$ and $0.5 \mathrm{~g}$ of Cobalt(II) complexes and dissolved in $2 \mathrm{ml}$ DMSO), and Zinc(II) complexes: (Add $2 \mathrm{ml}$ ethanol to each of $(0.1 \mathrm{~g}, 0.2 \mathrm{~g}$ and $0.3 \mathrm{~g}) \mathrm{Zinc}(\mathrm{II})$ complexes) . The petri plates were incubated at $37^{\circ} \mathrm{C}$ for 24 $\mathrm{h}$ in incubator midst which activity was appeared by the presence of a zone of inhibition $(\mathrm{mm})$ surrounding the well.

\section{Results and Discussion \\ Characterization of complexes synthesis}

5-(benzylideneamino)-1,3,4-thiadiazole-2thiol Schiff bases compound prepared through refluxing the aldehyde with 2-amino-5mercapto-1,3,4-thiadiazole and from this compound prepared complexes to improve biological activity all prepared compounds identification and characterizations by analytical and spectral methods. The FTIR spectrum for 5-(benzylideneamino)-1,3,4thiadiazole-2-thiol (Schiff bases compound), showed vibrational band at $\left(3407 \mathrm{~cm}^{-1}\right)$ due to $\mathrm{N}-\mathrm{H}_{\text {str }}[16]$ and band at $\left(1250.12 \mathrm{~cm}^{-1}\right)$ due to $\mathrm{C}=\mathrm{S}_{\mathrm{str}}$ this bands appearance because tautomerism phenomenon occur in 1,3,4thiadiazole-2-thiol ring at $(\mathrm{HS}-\mathrm{C}=\mathrm{N}-)$ in position 4 of the thiadiazole ring to form $(\mathrm{S}=\mathrm{C}-\mathrm{NH})$. The absorption bands at $\left(1642.11 \mathrm{~cm}^{-1}\right)$ due to $-\mathrm{C}=\mathrm{N}_{\text {str }}$ and appearance band at $\left(756.04 \mathrm{~cm}^{-1}\right)$ due to the C-S vibrational. In complexes appearance vibrational bands of $\mathrm{N}-\mathrm{H}_{\text {str }}$ between (3309.263147.6) $\mathrm{cm}^{-1}$, vibrational bands of $\mathrm{C}=\mathrm{N}_{\mathrm{str}}$ between $\quad(1634.92-\quad 1618.74) \mathrm{cm}^{-1}$ and vibrational bands of $\mathrm{C}=\mathrm{S}_{\text {str }}$ between (1152.281043.26) $\mathrm{cm}^{-1}$ are shift less than the vibrational bands of same groups in schiff bases compound this indicate the coordination occur and the vibrational bands of $\mathrm{C}-\mathrm{S}_{\text {str }}$ between (865.05- 801.43$) \mathrm{cm}^{-1}$ this value increase Compared to $\mathrm{C}$-S value in schiff bases compound. In complexes appearance vibrational bands of metal-N between (651.60$589.50) \mathrm{cm}^{-1}$ this indicated the coordination occurs between $\mathrm{N}$ in Schiff bases compound and metal.

Table (1)

Infrared Spectroscopy (FTIR) wave number $\mathrm{cm}^{-1}$ for Schiff base and complexes compounds.

\begin{tabular}{||c||c||c|c||c||c|}
\hline Groups & Schiff base & $\mathbf{A}_{\mathbf{1}}$ & $\mathbf{A}_{\mathbf{2}}$ & $\mathbf{A}_{\mathbf{3}}$ & $\mathbf{A}_{\mathbf{4}}$ \\
\hline \hline $\mathbf{N}_{-} \mathbf{H}_{\text {str }}$ & 3407 & 3308.47 & 3220.10 & 3147.6 & 3309.26 \\
\hline${\mathbf{C}=\mathbf{N}_{\text {str }}}$ & 1642.11 & 1630.11 & 1618.74 & 1625.67 & 1634.92 \\
\hline $\mathbf{C}=\mathbf{S}_{\text {str }}$ & 1250.12 & 1152.28 & 1044.32 & 1138.2 & 1043.26 \\
\hline${\mathbf{C}-S_{\text {str }}}$ & 756.04 & 865.05 & 801.43 & 860.10 & 802.49 \\
\hline Metal-N & - & 651.60 & 646.56 & 589.50 & 646.06 \\
\hline \hline Metal-Cl & - & 427.94 & 430.78 & 372.13 & 432.79 \\
\hline \hline
\end{tabular}

UV-visible spectrum of Schiff base compound $(\mathrm{C}=\mathrm{N})$ and $(\mathrm{C}=\mathrm{S})$ showed intense at $(224 \mathrm{~nm})$ and $(313 \mathrm{~nm})$ which refer to $\pi \rightarrow \pi^{*}$ and $n \rightarrow \pi^{*}$ electronic transition respectively, however its complexes occurs shifting the absorption band at $(307 \mathrm{~nm})$, (292nm), (272nm), (320nm) due to $A_{1}, A_{2}, A_{3}, A_{4}$ respectively that refer to electronic transition at $\pi \rightarrow \pi^{*}$ and $n \rightarrow \pi^{*}$ shown Table (2). 
Table (2)

Ultraviolet spectroscopy (UV-VIS) wave length $\lambda \mathrm{nm}$ for Schiff base and complexes compounds.

\begin{tabular}{|c||c||}
\hline Compound & $\begin{array}{c}\text { wave length } \boldsymbol{\lambda} \\
\text { (nm) }\end{array}$ \\
\hline \hline \multirow{2}{*}{ Schiff base compound } & 224 \\
& 313 \\
\hline \hline $\mathrm{A}_{1}$ & 307 \\
\hline $\mathrm{A}_{2}$ & 292 \\
\hline \hline $\mathrm{A}_{3}$ & 272 \\
\hline \hline $\mathrm{A}_{4}$ & 320 \\
\hline
\end{tabular}

\section{Identification of bacterial isolates}

The conformation tests of diagnostic bacterial isolate that depends on biochemical and phenotypic properties were described in Table (3).

Table (3)

Biochemical and morphological properties results of bacterial isolates.

\begin{tabular}{|c|c|c|c|c|c|c|c|}
\hline \multicolumn{2}{|c|}{$\begin{array}{l}\text { bacteria } \\
\text { tests }\end{array}$} & E. coli & $\begin{array}{c}P . \\
\text { mirabilis }\end{array}$ & $\begin{array}{c}C . \\
\text { freundii }\end{array}$ & $\begin{array}{c}P . \\
\text { aeruginosa }\end{array}$ & $\begin{array}{c}S . \\
\text { aureus }\end{array}$ & $\begin{array}{c}S . \\
\text { epidermidis }\end{array}$ \\
\hline \multicolumn{2}{|c|}{ Gram stain } & $\mathrm{G}^{-}$ve & $\mathrm{G}^{-}$ve & $\mathrm{G}^{-}$ve & $\mathrm{G}^{-}$ve & $\mathrm{G}^{+}$ve & $\mathrm{G}^{+}$ve \\
\hline \multicolumn{2}{|c|}{ catalase } & + & + & + & + & + & + \\
\hline \multicolumn{2}{|c|}{ oxidase } & - & - & - & + & - & - \\
\hline \multicolumn{2}{|c|}{$\begin{array}{l}\text { pigment } \\
\text { production }\end{array}$} & - & - & - & + & - & - \\
\hline \multicolumn{2}{|c|}{$\begin{array}{c}\text { Urease } \\
\text { production }\end{array}$} & - & + & V & - & - & + \\
\hline \multicolumn{2}{|c|}{ Hemolysis } & - & - & 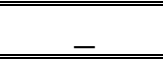 & + & + & 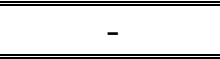 \\
\hline \multicolumn{2}{|c|}{$\begin{array}{c}\text { mannitol } \\
\text { fermentation }\end{array}$} & - & - & - & - & + & - \\
\hline \multirow{4}{*}{$\sum$} & IND & + & 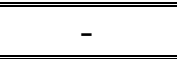 & - & 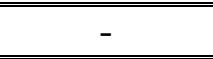 & ND & ND \\
\hline & MR & + & + & + & - & ND & ND \\
\hline & VP & - & - & - & - & ND & ND \\
\hline & $\mathrm{C}$ & - & + & + & + & ND & ND \\
\hline \multicolumn{2}{|c|}{$\begin{array}{c}\text { lactose } \\
\text { fermentation }\end{array}$} & + & + & + & - & - & - \\
\hline \multicolumn{2}{|c|}{$\begin{array}{l}\text { coagulase } \\
\text { production }\end{array}$} & - & - & - & - & + & - \\
\hline
\end{tabular}

$\mathrm{G}^{-}$ve: Gram negatine bacteria, $\mathrm{G}^{+}$ve: Gram positive bacteria, IND: indole, MR:methyl red, VP: Voges proskaur, C: Citrate utilization, ND: not done.

Sensitivity of bacterial isolates to antibiotics

The present study has displayed that the bacteria isolated from different site of infection have a high degree of resistance to most of the antibiotics under investigation. Table (4) showed that most of Gram positive and negative bacteria were sensitive to fluoroquinolones antibiotic such as Norfloxacin and Levofloxacin. This resistance may be due to bacteriocidal agents inhibit bacterial DNA by inhibiting the enzyme Isomerase I one of the enzymes of DNA Gyrase [17]. The antibiotic inhibits the process of dividing the cells during the process of binary fission, these antibiotic have two target sites in the bacterial cell. In other words, the resistant bacteria require two mutations, one of them in the site of the subunit A of DNA Gyrase and the other in the site of Topoisomerase IV. This reduces the bacterial 
resistance of this group of antibiotic, but the emergence of bacterial resistance against these antibiotics may be due to shifts in the target area or an increase in efflux pump system [18]. In the case of the antibiotic Amikacin, E.coli and P.mirabilis, exhibit intermediate resistance, S.aureus and S.epidermidis were sensitive while $P$. aeruginosa $C$.freundii were resistant to this, antibiotic. Amikacin is semimanufactured and derived from the antibiotic Kanamycin and effective against a large number of intestinal families and effective against the Gram-positive, because of its ability to inhibit protein synthesis [19]. The results of the present study show that the majority of bacterial isolates had a relatively high resistance to beta lactam antibiotic, such as the third generation of cephalosporins Ceftazidime. While Imipenem, a group of Carbapenems showed a high effectiveness against all types of bacterial isolates. The bacterial sensitivity to the beta lactam group is due to the ability of these antibodies to bind to the PBPs on the bacterial cell wall, thus inhibiting the manufacture of the bacterial cell wall. The bacteria's resistance to these antibodies is due to the ability of the bacteria to change the target sites targeted by the antibodies. These sites, such as penicillin G, are resisted by most of the Gram-positive bacteria, which produce the beta lactamase enzymes that break the beta lactam ring, change the permeability barrier or weaken the ligament between the antibiotic and target sites (PBPs) [20]. Also it can be seen that all Gram negative isolates were resistant to Carbencillin, whereas $S$. aureus and S. epidermidis showed high resistance against Azithromycin and Clarithromycin. The results in Table (4) showed that the bacterial isolates were sensitive to the Augmentin antibiotic this may be due To the production of chromosomal stimulated enzymes that are not inhibited by Clavulanic acid produced by E.coli and may be transmitted to other intestinal species such as P.mirabilis and C.freundii by bacterial conjugation [21]. Tigecycline antibiotic showed a relatively moderate resistance ratio, as shown in Table (4). This antibiotic is bacteriostatic inhibitors that inhibit the binding of aminoacyl-tRNA to the subunit (30S) of the bacterial ribosome. Bacteria resistance to tigecycline resistance results from the loss of bacterial outer membrane proteins, which reduces the permeability of the antibody into the bacteria [22].

Table (4)

resistance of bacterial isolates to antibiotics.

\begin{tabular}{|c|c|c|c|c|c|c|c|c|c|c|}
\hline Bacteria & TGC & NOR & LEV & IMP & CLA & CAZ & PY & ATH & AMC & $\mathbf{A K}$ \\
\hline E. coli & $\begin{array}{l}\mathrm{R} \\
14 \\
\end{array}$ & $\begin{array}{c}\mathrm{S} \\
18 \\
\end{array}$ & $\begin{array}{c}S \\
20 \\
\end{array}$ & $\begin{array}{c}S \\
22 \\
\end{array}$ & ND & $\begin{array}{c}\mathrm{R} \\
10 \\
\end{array}$ & $\begin{array}{l}\mathrm{R} \\
8 \\
\end{array}$ & ND & $\begin{array}{c}\mathrm{R} \\
12 \\
\end{array}$ & $\begin{array}{c}\mathrm{S} \\
17 \\
\end{array}$ \\
\hline P. mirabilis & $\begin{array}{l}\mathrm{R} \\
14\end{array}$ & $\begin{array}{c}\mathrm{S} \\
17\end{array}$ & $\begin{array}{c}S \\
22\end{array}$ & $\begin{array}{c}\mathrm{S} \\
20\end{array}$ & ND & $\begin{array}{c}\mathrm{R} \\
10\end{array}$ & $\begin{array}{l}\mathrm{R} \\
8\end{array}$ & ND & $\begin{array}{c}\mathrm{R} \\
12\end{array}$ & $\begin{array}{c}\mathrm{S} \\
18\end{array}$ \\
\hline C. freundii & $\begin{array}{l}\mathrm{R} \\
10 \\
\end{array}$ & $\begin{array}{c}\mathrm{R} \\
15 \\
\end{array}$ & $\begin{array}{c}S \\
18 \\
\end{array}$ & $\begin{array}{c}S \\
20 \\
\end{array}$ & ND & $\begin{array}{l}R \\
8 \\
\end{array}$ & $\begin{array}{l}\mathrm{R} \\
8 \\
\end{array}$ & ND & $\begin{array}{c}\mathrm{R} \\
10 \\
\end{array}$ & $\begin{array}{l}\mathrm{R} \\
14 \\
\end{array}$ \\
\hline P. aeruginosa & $\begin{array}{c}\mathrm{R} \\
8\end{array}$ & $\begin{array}{c}\mathrm{R} \\
14\end{array}$ & $\begin{array}{c}\mathrm{S} \\
18\end{array}$ & $\begin{array}{c}\mathrm{S} \\
20\end{array}$ & ND & $\begin{array}{l}\mathrm{R} \\
8\end{array}$ & $\begin{array}{c}\mathrm{R} \\
6\end{array}$ & ND & $\begin{array}{c}\mathrm{R} \\
10\end{array}$ & $\begin{array}{l}\mathrm{R} \\
12\end{array}$ \\
\hline S. aureus & $\begin{array}{l}\mathrm{R} \\
18\end{array}$ & $\begin{array}{c}\mathrm{S} \\
18\end{array}$ & $\begin{array}{c}S \\
20\end{array}$ & $\begin{array}{c}S \\
24\end{array}$ & $\begin{array}{c}\mathrm{R} \\
12\end{array}$ & $\begin{array}{c}\mathrm{R} \\
12\end{array}$ & ND & $\begin{array}{c}\mathrm{R} \\
10\end{array}$ & $\begin{array}{c}S \\
20\end{array}$ & $\begin{array}{c}\mathrm{S} \\
18\end{array}$ \\
\hline S. epidermidis & $\begin{array}{l}\mathrm{R} \\
16\end{array}$ & $\begin{array}{c}\mathrm{S} \\
18\end{array}$ & $\begin{array}{c}\mathrm{S} \\
20\end{array}$ & $\begin{array}{c}S \\
24\end{array}$ & $\begin{array}{c}\mathrm{R} \\
14\end{array}$ & $\begin{array}{c}\mathrm{R} \\
14\end{array}$ & ND & $\begin{array}{c}\mathrm{R} \\
10\end{array}$ & $\begin{array}{c}S \\
22\end{array}$ & $\begin{array}{c}S \\
20\end{array}$ \\
\hline
\end{tabular}

Ak: Amikacin, AMC: Augmentin, ATH: Azithromycin, PY: Carbencillin, CAZ: Ceftazidime, CLA: Clarithromycin, IMI: Imipenem, LEV: Levofloxacin, NOR: Norfloxacin, TGC: Tigecycline. 


\section{Antibacterial activity of complexes}

The growing numbers of antimicrobialresistant pathogens, which were increasingly linked with nosocomial contagion, place a considerable burden on healthcare systems and have important global economic costs. [23]. The complexes Cobalt(II) complexes, Ferric(III) complexes, Copper(II) complexes and Zinc(II) complexes were screened in vitro for their ability to inhibit the growth of some Gram negative pathogenic bacteria (E.coli, P.mirabilis, C.freundii and P.aeruginosa) and S.aureus and S.epidermidis as gram positive bacteria. It can be observed from Table (5) that the Cobalt (II) complexes exhibit high activity of inhibition at concentration $(0.1 \mathrm{M})$ against the bacterium $E$. coli clear zone of inhibition about $26 \mathrm{~mm}$. P. mirabilis, C.freundii, S.aureus and S.epidermidis with 20, 22, 22, 20 $\mathrm{mm}$ respectively. The zone of inhibition (ZOI) represent the activity of this complex on P.aeruginosa with less value $18 \mathrm{~mm}$, when compared with Imipenem antibiotic as an antibiotic with higher inhibitory efficacy than other antibiotics. Ferric(III) complexes exhibit less activity than Cobalt (II) complexes with the zone of inhibition $(24,16,18,20,18 \mathrm{~mm})$ for E.coli, P.mirabilis, C.freundii, S.aureus, and $S$. epidermidis respectively. Whereas the $P$ aeruginosa. exhibit less sensitivity with ZOI about $15 \mathrm{~mm}$ in concentration $0.3 \mathrm{M}$ compared with imipenem which have broad spectrum of activity against Gram positive and negative bacteria. Copper(II) complexes displayed a greater activity against all the studied pathogenic bacteria contrasted with Cobalt(II) complexes and Ferric(III) complexes as showed in Table (5). The highest antimicrobial activity observed against S.aureus and S.epidermidis with zone of inhibition about 26, $30 \mathrm{~mm}$ respectively at $0.3 \mathrm{M}$ concentration compared with $(24,24$ 22,22) for E.coli, P.mirabilis, C.freundii and P.aeruginosa respectively at the same concentration. The results of antibacterial activity of Zinc(II) complexes in concentration $0.3 \mathrm{M}$ revealed a broad spectrum of activity against various pathogens compared with Imipenem as showed in Table $(4,5)$. The higher value was $35 \mathrm{~mm}$ the ZOI of C.freundii, followed by 30 $\mathrm{mm}$ ZOI of E.coli and S. epidermidis while P.mirabilis and P. aeruginosa have $22 \mathrm{~mm}$ showed the zone of inhibition against zone of inhibition. (Fig. 1,2,3 and 4 some pathogenic bacteria). Several studies were investigate the effectiveness of Thiadiazoles and its derivatives on varies pathogenic microbes as a new treatment, so this results was similar to [24] who demonstrated that the [3dicyclohexyl amino methyl -2mercaptobenzothiazole] [L] and its derivatives have high activity against E.coli and S.aureus. Also our results come in consistence with [25] who synthesized N-benzylidene- 5-phenyl1,3,4-thiadiazole derivatives.
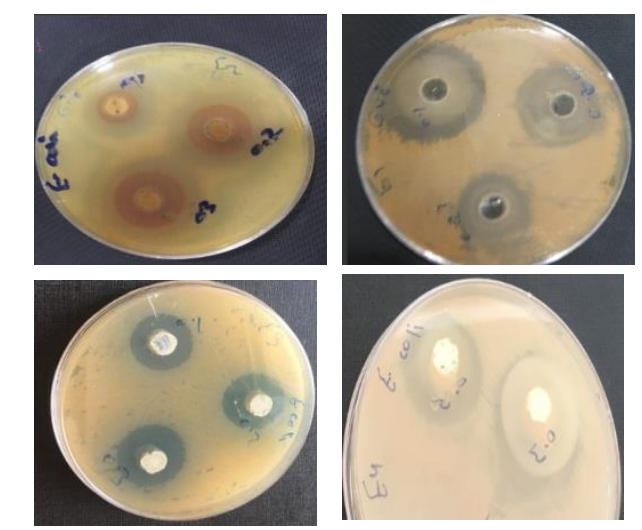

Fig.(1): Activity of $A_{1}, A_{2}, A_{3}$ and $A_{4}$ on E.coli.
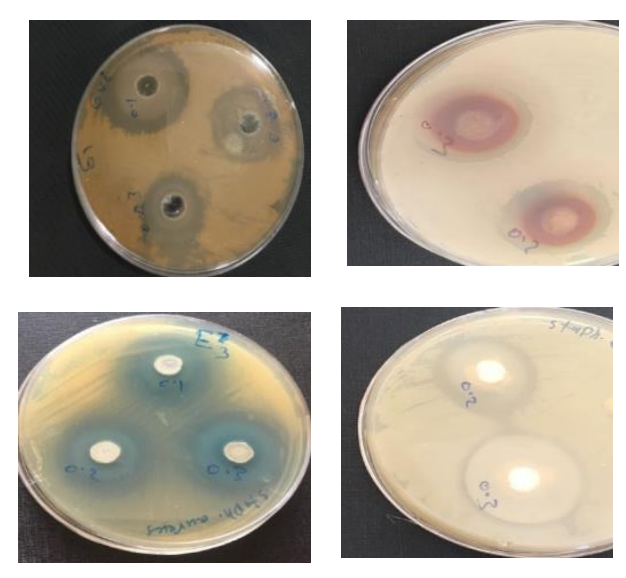

Fig.(2): Activity of $A_{1}, A_{2}, A_{3}$ and $A_{4}$ on S.aureus.

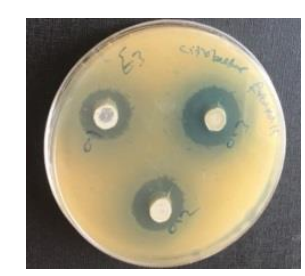

Fig.(3): Activity $A_{1}$ on C.freundii. 


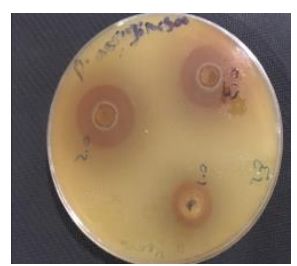

Fig.(4): Activity of $A_{2}$ on P. aeruginosa Conclusion.

Zinc (II) complexes have the greater activity against pathogenic bacteria compared with other complexes and Imipenem antibiotic, followed by Copper (II) complexes which exhibit a higher effectiveness toward Gram

Table (5)

Antibacterial activities of complexes.

\begin{tabular}{|c|c|c|c|c|c|c|c|c|}
\hline Bacteria & con./M & $\mathbf{A}_{3}$ & con./M & $\mathbf{A}_{2}$ & con./M & $\mathbf{A}_{1}$ & con./M & $\mathbf{A}_{4}$ \\
\hline \multirow{3}{*}{ E.coli } & 0.05 & 16 & 0.1 & 18 & 0.1 & 20 & 0.1 & 20 \\
\hline & 0.03 & 20 & 0.2 & 22 & 0.2 & 22 & 0.2 & 25 \\
\hline & 0.1 & 26 & 0.3 & 24 & 0.3 & 24 & 0.3 & 30 \\
\hline \multirow{3}{*}{ P.mirabilis } & 0.05 & 12 & 0.1 & 10 & 0.1 & 18 & 0.1 & 12 \\
\hline & 0.03 & 16 & 0.2 & 14 & 0.2 & 22 & 0.2 & 20 \\
\hline & 0.1 & 20 & 0.3 & 16 & 0.3 & 24 & 0.3 & 22 \\
\hline \multirow{3}{*}{ C.freundii } & 0.05 & 12 & 0.1 & 16 & 0.1 & 12 & $\overline{0.1}$ & 22 \\
\hline & 0.03 & 16 & 0.2 & 22 & 0.2 & 16 & 0.2 & 26 \\
\hline & 0.1 & 22 & 0.3 & 18 & 0.3 & 22 & 0.3 & 35 \\
\hline \multirow{3}{*}{ P.aeruginosa } & 0.05 & 10 & 0.1 & 10 & 0.1 & 16 & 0.1 & 15 \\
\hline & 0.03 & 14 & 0.2 & 12 & 0.2 & 20 & 0.2 & 20 \\
\hline & 0.1 & 18 & 0.3 & 15 & 0.3 & 22 & 0.3 & 22 \\
\hline \multirow{3}{*}{ S.aureus } & 0.05 & 16 & $\begin{array}{l}0.1 \\
\end{array}$ & 12 & 0.1 & 20 & $\begin{array}{l}0.1 \\
\end{array}$ & 16 \\
\hline & 0.03 & 20 & 0.2 & 15 & 0.2 & 22 & 0.2 & 22 \\
\hline & 0.1 & 22 & 0.3 & 20 & 0.3 & 26 & 0.3 & 30 \\
\hline \multirow{3}{*}{ S.epidermidis } & 0.05 & 14 & 0.1 & 10 & 0.1 & 22 & 0.1 & 14 \\
\hline & 0.03 & 18 & 0.2 & 15 & 0.2 & 26 & 0.2 & 18 \\
\hline & 0.1 & 20 & 0.3 & 18 & 0.3 & 30 & 0.3 & 26 \\
\hline
\end{tabular}

\section{Acknowledgement}

A special thank goes to Department of Chemistry, College of Science, Al-Nahrain University, Department of Biology, College of Education, Samarra University and Department of Pathological Analyzes, College of Applied Sciences, Samarra University for their outstanding assistance to perform this research.

\section{References}

[1] Georgeta S., Stela C., Eva E. and Anamaria S., "Synthesis of Some 2-r-5-Formil-1,3,4Thiadiazole Derivatives by Sommelet Reaction", journal of Farmacia, 58(6), 811822, 2010. positive compared with Gram negative bacteria. Cobalt (II) complexes revealed moderate activity when compared with other complexes (Zinc(II) complexes and Copper(II) complexes) but in compared with Imipenem, $\mathrm{P}$ aeruginosa showed a slight resistance toward Cobalt (II) complexes. Ferric (III) complexes was exhibit less activity compared with other complexes and imipenem, but when compared with other antibiotic this complex showed a good activity as showed in Table $(4,5)$.

[2] Vasiliy A., Valeriy O., Lidia N., Kristina A.,Tetyana V. and Mikhail S., "Switchable Rearrangements in 1,2,3-Thiadiazole and 1,2,3-Triazole Series", Book of Abstracts International Society of Heterocyclic Chemistry, 94, 2017.

[3] Bakulev V. and Dehaen W., "The Chemistry of 1,2,3-Thiadiazoles", John Wiley and Sons Inc., Hoboken, Heidelberg, New York, Dordrecht, London, 384, 2004.

[4] Ana A., Panagiotis M. and Zoumpoulakis M., "Sulfonamide-1,2,4-thiadiazole Derivatives as Antifungal and Antibacterial Agents: Synthesis, Biological Evaluation, Lipophilicity and Conformational Studies", 
Journal of Chemical and Pharmaceutical Bulletin.58, 160-167, 2010.

[5] Roger F., Greenwood D., Norbby S., and Whitley R. "Antibiotic and Chemotherapy, The problem of resistance", Journal of Churchill Livingstone, 25-47, 2003.

[6] Ispir E., Kurtoglu M. and Purtas F., "Synthesis and antimicrobial activity of new Schiff bases having the $-\mathrm{SiOR}$ group ( $\mathrm{R}=\mathrm{CH}_{3}$ or $\mathrm{CH}_{2} \mathrm{CH}_{3}$ ), and their transition metal complexes". Journal of Trans. Met. Chem., 30, 1042-1047, 2005.

[7] Ahlam A. and Ahlam J., "Synthesis and Antibacterial Activity of bis Heterocyclic Derivatives of 1,3,4-thiadiazole", Journal of Iraqi Pharm Sci, 24(1), 59-67, 2015.

[8] Salih N. A., "Synthesis of New Heterocyclic Compounds derived from 2Amino-5-Mercapto-1,3,4-Thiadiazole", Phd. Thesis, College of Science, AL-Nahrain University, 2005.

[9] Abdul-Jabar K., Fouad M., Aoras A., "Synthesis, Characterization and Antibacterial Activities of Some New $\beta$-Lactam Thiadiazole Derivatives", Journal of AlMustansiriyah Sci., 25, 103-112, 2014.

[10] Kadhim K. Ghudhaib, Shaimaa R. Bakir and Ekbal R. Hanna, "Antimicrobial Activity of Some 1,3,4-Thiadaiazole Metal Complexes", Journal of Al-Nahrain University 17(2), 1-8, 2014.

[11] Singh K, Raparia S. and Surain P., "Co(II), Ni(II), $\mathrm{Cu}(\mathrm{II})$ and $\mathrm{Zn}(\mathrm{II})$ Complexes of 4-(4-cyanobenzylideneamino)-3-mercapto5-oxo-1,2,4 triazine: synthesis, characterization and biological studies." Journal of Medicinal Chemistry Research, 24(24), 2336-2346, 2015.

[12] Mahon C., Manuselis G.and Lehman D., "Textbook of Diagnostic Microbiology", Elsevier 5rd ed. USA: Saunders Company, 868, 2015.

[13] Bauer A., Kirby W., Sherris J. and Turch M., "Antibiotic susceptibility testing by a standardized single disk method. Journal of Clin Pathol., 45(4), 493-496, 1966.

[14] Wayne P., "Performance Standards for Antimicrobial Susceptibility Testing", Clinic and Laboratory, 26, 2007.

[15] Egorove N., "Antibiotics a scientific approach 1st ed., MIR. Puplisher, 418, 1985.
[16] Jber N.R., Abood R.S. and Al-Dhaief Y.A., "Synthesis and Spectral Study of New Azo-Azomethine Dyes and its Copper (II) Complexes Derived from Resorcinal, 4Aminobenzoylhydrazon and 4-Amino antipyrine", Journal of Al-Nahrain University, 14 (4), 50-56, 2014.

[17] Presccott L., Harley J. and Klein D., "Microbiology", McGraw-Hill. Publication 66. Ann ICRP, 24, 1-3, 2005.

[18] Johnson R., Kuskowski A., O'Bryan T., Raul C. and Raz R., "Virulence genotype and phylogenetic origin in relation to antibioti resistance profile among Escherichia coli urine sample isolates from women with acute uncomplicated cystitis". Journal of PubMed Antimicrobial Agents and Chemotherapy, 49, 26-31, 2005.

[19] Rotschafer C. and Peterson M., "Aminoglycoside tutorial", University of Minnesota, 2004.

[20] Talaro K., "Foundation in Microbiology Basic Principles", McGraw Hill, ISBN 007-295077-3, 2010.

[21] Karlowsky A., Kelly L. and Sahm F., "Trends in antimicrobia resistance among urinary tract infection isolates of $\mathrm{E}$. coli from female outpatients", Antimicrob. Agents. Chemother. 46(8), 2540- 2545, 2002.

[22] Brooks G., Butel J. and Morse S., "Jawetz, Melenik and Adelberg's Medical Microbiology", 23rd ed the McGraw- Hill companies. Appleton and Lange. New York, 2007.

[23] Bush K., Jacoby G., "Updated functional classification of $\beta$-lactamases", Antimicrobial Agents and Chemotherapy, 54(3), 969-976, 2010.

[24] Rehab A. and Eiman S., "Synthesis, Characterization and Biological Activities of Mixed Ligand Complexes of Mannich Base Derived from 2Mercaptobenzothiazole", Journal of AlNahrain University 17(2), 73-84, 2014.

[25] Seelam N., Shrivastava S. and Prasanthi S., "Synthesis and antimicrobial activity of some novel fused heterocyclic moieties". Journal of Org. Commun., 6(2), 78-85, 2013. 